\title{
Teachers in the Context of Vocational Education
}

\author{
Gabriela Gabrhelová - Lenka Pasternáková ${ }^{*}$
}

Received: June 22, 2016; received in revised form: November 2, 2016; accepted: November 3, 2016

\begin{abstract}
In the presented article, we deal with teachers' personality and their tasks in vocational education. Based on the opinions of professionals, we characterized teachers and the factors influencing the creation process of their personality. Teachers can be characterised based on their job positions in schools, e.g. a class teacher, the school counsellor, the director, there are plenty of them in every school. Teachers' personality is being formed throughout their teaching practice by the experience they gain. They get the basics during their teacher training when they are getting prepared for the teaching profession. We focused our attention on the issues of teachers' professional identity. In this context, we were interested in the students of Dubnica Institute of Technology in Dubnica nad Váhom and in their perception of their studies. Our partial goal was to analyse students' motivation to take part in teacher training which we deal with in our paper.
\end{abstract}

Key words: teacher, school, vocational school, teaching profession, motivation.

\section{Introduction}

In every description of the teaching profession, it is important to have in mind that the socio-professional groups of teachers are internally differentiated. This way, various typologies of teachers are created. The most notable typology of teachers is based on the type and the level of the school they work at. From our point of view, in pedagogy, personality is seen in the context of personality development or in relation to the specifics of teachers' personalities. Not in

\footnotetext{
* Gabriela Gabrhelová, Dubnica Institute of Technology in Dubnica nad Váhom, Dubnica nad Váhom, Slovakia; gabrhelova@dti.sk

Lenka Pasternáková, Faculty of Humanities and Natural Sciences, University of Prešov, Prešov, Slovakia; lenka.pasternakova @ unipo.sk
} 


\section{Acta Technologica Dubnicae \\ volume 6, 2016, issue 3}

every profession do personality traits play such an important role as it is in the case of teachers. It is the teacher who inspires students to develop their professional and human potential to the greatest possible extent. Teachers should deal with specific problems. On one hand, teachers have much less freedom in their profession than creative artists but on the other hand, they operate in a space completely different from the space of a technician.

\section{Teachers' personality}

Teaching competencies are not only what teacher trainees earn during their studies, but also the extent to which a particular employee is personally equipped for working in the teaching profession. Fontana (2010) divided personality components as follows:

- professional competencies - pedagogical, didactic, psychological;

- performance competencies - working ability, physical ability, coping with stress;

- personal competencies - volitional characteristics, character, social skills, communication skills, interpersonal relationships;

- $\quad$ social competencies - moral values, bearer of values;

- motivational competencies - identification with the role of a teacher, realization of the teacher's role.

It is a very demanding task to define the notion of personality exactly as its understanding changes in accordance with the point of view of psychologists, pedagogues or sociologists. Teachers' personality should be understood as a general model of personality characteristic by its psychical determination (Hupková \& Petlák, 2004).

Teachers' influence and personality development are determined mainly by their innate characteristics, i.e. teaching giftedness, self-education, the intensity of teachers' interest. In this context, it is natural to expect certain educational giftedness, talent and skills. It can be defined as a sum of personality traits determining the success of educational work. Especially loving children; cognitive characteristics (thinking, imagination, memory, attention); personality traits (character, volitional qualities, working qualities, emotional temperament, and social character traits); particularities of personal life and behaviour belong here (Ďurič \& Štefanovič, 1977).

Teachers' personalities are influenced by the characteristics and the quality of their relationship with students. The character and the quality of teachers' relationships with teachers have an impact on their personalities, too. Teachers influence the classroom climate and promote or inhibit students' interest in the 


\section{Acta Technologica Dubnicae \\ volume 6, 2016, issue 3}

subject that they teach. They also manage students' development, their knowledge and whole personality. That is why there are high requirements on teachers and their personalities regarding a high degree of moral and volitional qualities. They should become role models for their students. They influence students by their personality, by their appearance and their overall behaviour not only in school but also in private lives. It applies to teachers' personality in general and so does to the teachers of technical subjects.

For the reasons mentioned above, teachers' personality is the key to their success in their teaching practice. Whether a teacher is an authority for students or not, is popular or hated by students, depends on him/her. And it is up to them whether they have a small, big or no impact on students in the educational process. Based on our experiences and as stated by various authors (e.g. Határ, 2012; Dupkala, 2004; Tamášová, 2015), students do not like teachers which are strict and critical, because they are losing their self-confidence, are neither initiative nor independent. In the case of liberal teachers, students are pushing the limits of how far they can go and, thus, create unfavourable conditions for learning. Psychological particularities of teachers are reflected especially in their relationships with others. They are sensitive personalities with a sensitive approach to others. They are willing to help, give advice and to sacrifice (Škvarková, 2005).

In the process of creating teachers' personality, verbalization and thinking are very important. It is the ability to express own thoughts, an increased level of intelligence, and the ability to express oneself briefly, clearly and comprehensibly. Personality traits such as mental freshness and youth, openness to new stimuli, a good sense of humour, a sense of justice, etc., are especially important. In accordance with the findings by Błażejewski and Lewicki (2011), a teacher should be empathic, friendly, responsible, systematic, personally mature and mentally healthy. Successful teachers plan their lessons more carefully, dedicate more time to after-school activities and show more interest in students than the less successful ones. It does not mean that teachers should build an emotional relationship with students. Those teachers who develop an emotional relationship with their students are not fair to each student, they are not able to approach their students with an objective professionalism and, on the other hand, students may have the feeling that they have to fulfil very high requirements. In the case of teachers, it is important to have a positive relationship with their students and like the work with them, but they must not forget about the emotional distance and responsibility.

According to Dytrtová and Krhutová (2009), novice teachers should bear responsibility for the organization and planning activities in the classroom, to have developed professional competencies and a good base of knowledge that 


\section{Acta Technologica Dubnicae \\ volume 6, 2016, issue 3}

they use to make their students' learning easier; should use appropriate methods of assessment and to lead students throughout the educational process properly; should be able to create a good social climate; to maintain professionalism (to behave and act properly); and be capable of self-awareness and self-evaluation also through others, e.g. colleagues.

In the Middle Ages, the teaching profession was connected to religious education, i.e. education took place in cathedral and monastery schools for the purposes of training the clergy. The teachers - priests - taught mainly theology or scholastic philosophy in Latin. Universities founded in Europe in the 12th century, e.g. in Oxford (1168), in Bologna (1224) or in Prague (1348), brought a turning point in the teaching profession. Universities not only did contribute to the development of education in general (to some extent independently from church) but also did they produce a new type of professional educators university teachers. From the beginning of the 17th century, the development of the teaching profession has been influenced by pedagogical theories by great humanist thinkers such as J. A. Comenius, J. J. Rousseau or J. H. Pestalozzi. These pedagogues and philosophers focused their work above all on school and education theory and thus brought changes in the character of the teaching profession. In the history of the Slovak teaching profession, the school reforms during the reign of Maria Theresia became an important milestone. The substance of this model lies in the introduction of compulsory education and establishing three types of elementary schools: trivial, main and normal schools (Dupkala, 2014).

Based on the overview of typologies of teachers' personalities, we can state that there is not one particular type of teachers' personality as there is no ideal teacher. Also individual typologies are interconnected and overlapped. It is not possible to specify what kind of interaction with students is the most appropriate. For future teachers, a good orientation in various typologies and the ability to answer a huge amount of questions are very important as well as dealing with demanding situations.

Finding own professional identity is a long-time process which is closely connected to searching for personal identity. It is not easy to define the notion of identity. In general, we can say that in the process of searching for identity, people try to find themselves, to become themselves. The professional identity of teachers can be characterised similarly to personal identity, but it is determined by their professional confidence, self-confidence, self-reflection, self-knowledge and awareness of own professional qualities. Being a teacher is not only a profession, it is a mission as well. It represents self-sacrificing care and participation in the development of new generations. Independence and responsibility are important in the work of teachers, they reflect their mental 


\section{Acta Technologica Dubnicae \\ volume 6, 2016, issue 3}

stability, power and the resilience of their personality. Teachers are professionals which educate and lead towards wisdom and love.

Every teacher needs time to become a good teacher in order to survive various pedagogical and didactic situations. The length or the period of adaptation is not the same with every teacher. It depends on the novice teachers' interest in their job, individual systematic studies and the collective in which they work. It means that their pedagogical competencies develop gradually and the whole process can be characterized by several levels. The process of "becoming a teacher" takes several years. The opinions regarding the length or the duration of this period differ. Some professionals talk about five years, others about eight to ten years. For sure, every teacher needs some time to become a good teacher, to try out and to experience various educational and didactic situations.

In the context of pedagogical competencies, we must mention the types of pedagogical competencies, too. Švec (2002) divides pedagogical competencies into the following three groups:

a) teaching competencies: diagnostic, psychological, educational and communication skills;

b) personal competencies: e.g. teachers' responsibility for own decisions during the educational process, authenticity, acceptance of oneself and others;

c) developmental competencies: adaptability, information, research, selfreflection and self-regulation skills.

According to Višňovský and Kačáni (2005), we can distinguish the following competencies:

a) interpretation - when teachers mediate knowledge, update it and use optimal teaching methods in the process of education;

b) self-creation - teachers make inquiries for the purposes of selfdevelopment, they are the creators of own pedagogical knowledge;

c) realization - when the work of teachers is focused on the realization of the set educational goals and values with not only one class, but the whole school. 


\section{Acta Technologica Dubnicae \\ volume 6, 2016, issue 3}

\section{Survey}

People choose the teaching profession for various reasons. In our survey, we deal with the motivation of students to study at Dubnica Institute of Technology in Dubnica nad Váhom. This institute provides candidates with teacher training. In this context, a survey on the sample of 195 respondents consisting of external students in the second year of the Master's program at Dubnica Institute of Technology has been realised.

\subsection{Survey objectives}

The partial objective of the survey was to learn about the respondents' opinions regarding a particular institute. In this context, we were interested in their motivation for studying at Dubnica Institute of Technology and how satisfied they were. By means of a survey, we intended to find out what the source of information regarding the possibilities of studying at Dubnica Institute of Technology was and whether they intended to work in the field of their studies in their future lives.

\subsection{Key findings}

In the first round of the survey, we intended to find out the reasons why the respondents, i.e. DTI students, had decided to study at this particular institute. By means of a questionnaire, we found out that the most frequent reason was the "reasonable" or "acceptable" school fee (36.92\%). One quarter of the respondents made their decision based on the fact that the institute was near their residence (25.13\%). 23.08\% of the respondents was interested in a particular study program offered by Dubnica Institute of Technology and, therefore, decided to study there. $6.15 \%$ of the participants responded that they did not care what they studied, they only needed a Master's degree. Dubnica Institute of Technology was recommended by their parents to $5.64 \%$ of the respondents; by their school counsellor to $2.05 \%$ and by their friends to $1.03 \%$ of them.

The respondents' most frequent answer regarding the reasons for choosing a particular field of study was that they wanted to continue in their studies $(54.37 \%)$ and wanted to become teachers $(20.51 \%) .13 .33 \%$ of the participants indicated that they only wanted to earn a Master's degree; these respondents were not satisfied with their Bachelor's degree. $7.69 \%$ indicated that their studies were required by their current job position. $4.10 \%$ of the participating students responded that after finishing the Bachelor's program, it was the only available option (Table 1, Figure 1). 
Table 1

Participants' reasons for choosing a particular field of study

\begin{tabular}{lcc}
\hline & $\underline{\mathrm{N}}$ & $\underline{\%}$ \\
$\begin{array}{l}\text { a) I want to become a teacher } \\
\text { b) I only want to earn } \\
\text { a Master's degree }\end{array}$ & 40 & 20.51 \\
c) My current job position & 26 & 13.33 \\
$\quad$ requires it & 15 & 7.69 \\
d) After finishing the & 8 & 4.10 \\
$\quad \begin{array}{l}\text { Bachelor's program it was } \\
\text { the only available option }\end{array}$ & & \\
e) I want to continue in & & 54.37 \\
education & 106 & 0 \\
f) Other response & 0 & 100 \\
Total & 195 & \\
\hline
\end{tabular}

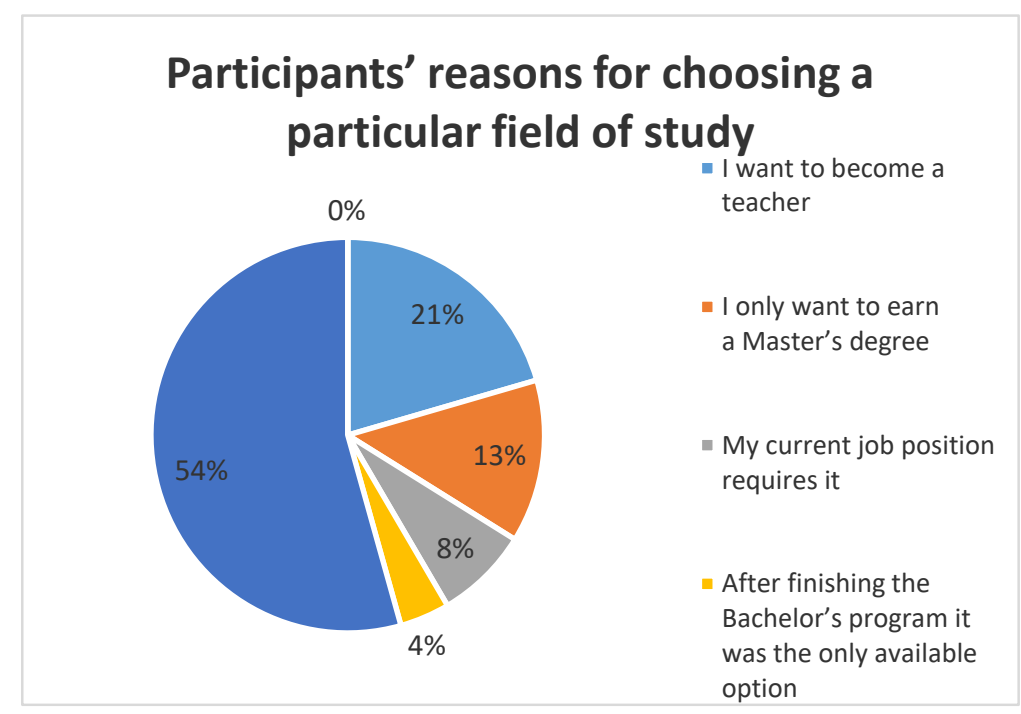

Figure 1. Participants' reasons for choosing a particular field of study. 


\section{Acta Technologica Dubnicae \\ volume 6, 2016, issue 3}

Taking into account the large scale of available study programs offered by colleges and universities in Slovakia and abroad seeking to attract students, we tried to find out about the respondents' sources of information regarding the opportunity to study at Dubnica Institute of Technology.

In Table 2 and Figure 2 we can see that three thirds of the respondents heard about the opportunity to study at Dubnica Institute of Technology from friends and acquaintances (77.44\%). 7.18\% got the information from the university portal and $6.67 \%$ form the school counsellor. 5.64\% had information from advertisement boards and $3.08 \%$ from the website. These data are interesting as the fact that "the best advertisement" is someone's personal experience distributed, e.g. verbally, was approved again.

Table 2

Respondents' sources of information regarding the opportunity to study at Dubnica Institute of Technology in Dubnica nad Váhom

\begin{tabular}{lcc}
\hline & $\underline{\mathrm{N}}$ & $\underline{\%}$ \\
$\begin{array}{l}\text { a) From friends and } \\
\text { acquaintances }\end{array}$ & 151 & 77.43 \\
$\begin{array}{l}\text { b) From advertisements } \\
\text { in newspapers }\end{array}$ & 0 & 0 \\
c) From advertisement \\
boards
\end{tabular}




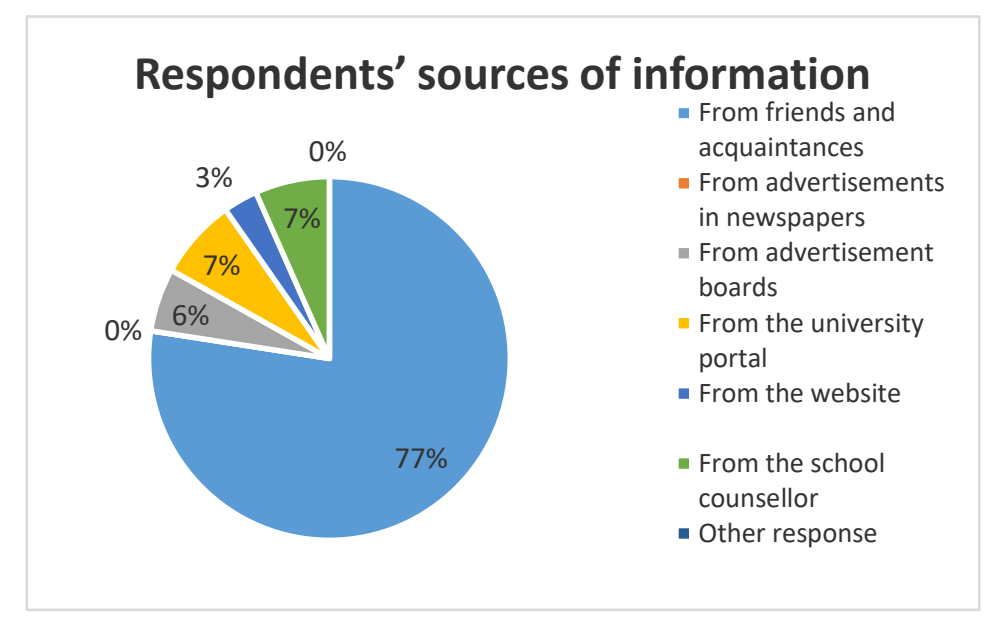

Figure 2. Respondents' sources of information regarding the opportunity to study at Dubnica Institute of Technology in Dubnica nad Váhom.

We also asked the respondents, i.e. students of the second year of the Master's program, whether their studies at Dubnica Institute of Technology in Dubnica nad Váhom had fulfilled their expectations. In the case of this item, we received mainly positive answers, which is a pleasant finding. $61.03 \%$ of the participants indicated "rather yes", $18.97 \%$ "yes" and $11.79 \%$ "rather no". In this item, $8.21 \%$ of the respondents did not express their opinions. Based on the above mentioned, we can state that the expectations of the students of Dubnica Institute of Technology related to their studies were fulfilled.

In the next step we intended to inquire into the extent of satisfaction with the quality of education at Dubnica Institute of Technology in Dubnica nad Váhom. The findings were positive again. The option "rather yes" was selected by $65.13 \%$ of respondents. $28.21 \%$ of the participants was satisfied, which is almost one third of the respondents. $6.67 \%$ respondents was unable to comment on it. We were pleased by the mentioned findings again as it is extremely important that students are satisfied with the quality of education in which they take part and which they pay for. 


\section{Acta Technologica Dubnicae \\ volume 6, 2016, issue 3}

In one part of the questionnaire, we asked the participants whether they intended to find a job related to the studied profession. One half of them (49.74\%) responded "yes". One quarter of the respondents (25.64\%) responded "rather yes" in this item. Basically, they would like to work in the studied profession. $9.74 \%$ of the respondents indicated that they would rather not work in the studied field. Only one respondent from the whole sample indicated that he/she was sure that would definitely not work in the studied field $(0.51 \%)$.

We also asked the respondents whether they were interested in the job position of a class teacher in case of working in the sphere of education after their graduation. $34.36 \%$ of the respondents answered "rather no". $10.77 \%$ of them indicated "no". $18.46 \%$ of the participating students would like to become a class teacher and $6.15 \%$ of them indicated the option "rather yes" in this item. As much as one third of the sample (30.26\%) was unable to comment on it. Based on the gather data, we can declare that the survey participants do not want to become class teachers or they do not know yet. This fact may be an indicator of their level of responsibility, but also of a lack of experience in the particular profession. Their responses might be a reflection of their experience gained during their teaching practice which is a part of their studies.

We were interested whether they would decide to study at Dubnica Institute of Technology again. More than one half of the participants responded "yes" to the question. $13.33 \%$ of the participants answered "yes" and $40 \%$ "rather yes". It is a positive finding for the management of Dubnica Institute of Technology in Dubnica nad Váhom. One third of the respondents (27.18\%) was unable to comment on it. $15.90 \%$ of the respondents would not choose Dubnica Institute of Technology for their studies again. 3.59\% of the sample indicated "no" in this item. We received positive answers for the question whether the respondents students of Dubnica Institute of Technology - would recommend studying at this institute to other applicants. $32.31 \%$ of them responded "yes" and as much as $46.67 \%$ responded "rather yes". $14.87 \%$ of the participants could not decide. Only $6.15 \%$ of the participants indicated the option "rather no". Our findings show that the respondents are satisfied with their choice of the institute and the selected field of study. The participants study what they are really interested in, which is a positive finding (Table 3, Figure 3). 
Table 3

Recommendation to study at Dubnica Institute of Technology in Dubnica nad Váhom to other applicants by the respondents

\begin{tabular}{lcc}
\hline & $\underline{\mathrm{N}}$ & $\underline{\%}$ \\
a) Yes & 63 & 32.31 \\
b) Rather yes & 91 & 46.67 \\
c) I do not know & 29 & 14.87 \\
d) Rather no & 12 & 6.15 \\
e) No & 0 & 0 \\
Total & 195 & 100 \\
\hline
\end{tabular}

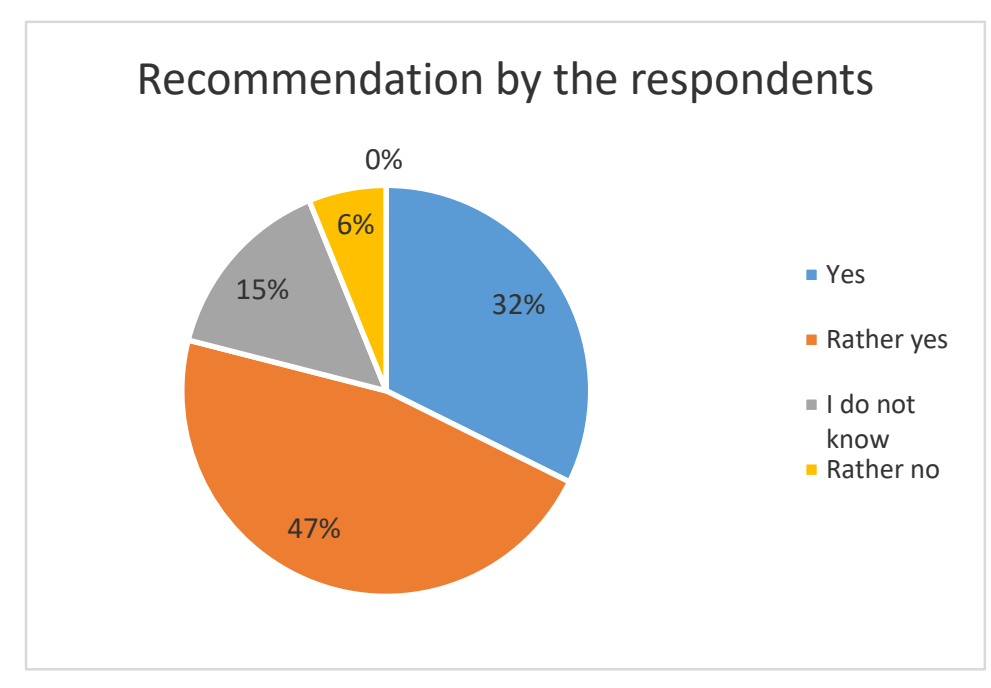

Figure 3. Recommendation to study at Dubnica Institute of Technology to other applicants by the respondents.

By means of one of the survey questions, we intended to find out what would the participants do to avoid burnout if working in the teaching profession. They most frequently responded that they would try to spend their leisure time actively, to relax and get energy for working in the sphere of education. Others 


\section{Acta Technologica Dubnicae \\ volume 6, 2016, issue 3}

would, according to their responses, consider a change in their approach to their job, they would definitely live an active life. The respondents highlighted the importance of "changing the environment". They found "not taking work home" important, otherwise there would be no time left for their hobbies and "themselves". Some of them mentioned the importance of further education.

In this context, we would like to highlight the response given by one of the female participants who wrote, "It is important to search for the positives in what we do, to move further and to set new goals". According to some respondents, being a part of a good working collective characterised by mutual help and support is crucial. Many of the participants also highlighted the importance of approaching problems with ease. Some of them responded that they were not endangered by burnout as being "very active people".

Finally, we can state that the respondents have an idea how they would handle with or prevent the burnout syndrome. They know about the risks of being a teacher, despite it, most of them would like to work in the teaching profession. The respondents were motivated to study at Dubnica Institute of Technology in Dubnica nad Váhom mainly by the height of the school fee and the fact that it was close to their residence. They chose their field of study because they wanted to continue in their education and really wanted to become teachers. In most cases, they learned about the opportunity to study at Dubnica Institute of Technology from their friends and acquaintances. According to the participants, their studies at Dubnica Institute of Technology in Dubnica nad Váhom have fulfilled their expectations. They are "rather satisfied" with the quality of education at the institute. In the future, the participants intend to work in the studied profession but they would rather not be at the job position of a class teacher. If they had to decide, they would have chosen Dubnica Institute of Technology again and they would recommend this institute to other applicants, too.

It is generally known that the teaching profession is a demanding one. For a teacher, it is extremely important to be a mentally healthy personality. Both traditional and modern pedagogues have introduced various requirements on teachers' personality, e.g. Comenius required piety, virtue, didactic skills and a positive approach to their job. Pestalozzi emphasised the "educational substance". Herbart accentuated "scientific knowledge". Diesterweg required teachers' mastery of the subjects they teach and that they should love their job, be universally, but, above all, pedagogically and psychologically educated and emphasized permanent self-education. L. N. Tolstoy considered good teachers those who "are able to explain topics to their students", to discover new methods and love children as well as their profession. The Polish pedagogue J. W. Dawid called for intellectual and emotional relationship which he calls "love of human 


\section{Acta Technologica Dubnicae \\ volume 6, 2016, issue 3}

souls". Besides that, Comenius called for teachers' wisdom, sanity and decency, according to him, teachers must love their profession and have to learn the art of teaching (Černotová, 1997).

As times have changed, the opinions and the requirements on good teachers have changed as well. We agree with the opinion of authors which named those teachers' basic predispositions that transform their teaching activity into a functional educational process. Many teachers are good, some of them are bad but we were interested in what the students, i.e. the objects of the educational process, understand under these attributes. Based on other realized research, according to older school-age children, a good teacher has a friendly approach to all students, is strict and is able to explain topics. Good teachers can be characterised by understanding their students, knowing how to mediate knowledge to them, by their willingness to give students advice, they are sincere, straightforward and honest. Good teachers treat all their students equally, have good relationships with them, do not keep too much distance, are able to attract students, are willing to help them and are happy to do so, but, above all, good teachers are good psychologists as not only do they teach but they educate. They are fair in assessment, are optimistic with a good sense of humour, are calm, have self-control and conscientiously fulfil their duties. Middle school-age children have described a bad teacher very similarly to the older school-age children. According to them, bad teachers are those which do not possess sufficient knowledge from the school subject they teach, are too strict, keep distance from their students and do not treat their students equally. Dytrtová and Krhutová (2009) mention that these teachers keep making fun of their students, are ironic, are scolding them, giving them nicknames, yelling at them for nothings, do not understand them, have bad relationship with them or are not strict enough. Those are the teachers which are not able to explain topics well, create a bad social climate, require memorizing, have negative personal qualities, are moody and do not conscientiously fulfil their duties.

It is the sum of teaching knowledge, skills, personality traits and behaviour that makes a teacher. They are the key elements leading towards the success of the educational process. Teachers' personal qualities depend on the application of their teaching knowledge and skills. Teachers' personalities have an impact on the character and the quality of their relationship with students, determine the classroom climate, the development of their knowledge and the whole personality. By their behaviour, teachers educate children and serve as role models to children which imitate them (Jakúbek \& Tej, 2015). 


\section{Acta Technologica Dubnicae \\ volume 6, 2016, issue 3}

\section{Conclusions}

Based on the analysed issues, we can state that there does not exist a single definition of a teacher including all the positive characteristics mentioned by every author. Each personality contains something from positive personality traits but no one will ever become an ideal teacher who is unmistakable or perfect. Teachers can make a step towards excellence only if they are interested in their own permanent development and have in mind that their profession is one of the most important ones and teachers are those which, after parents, help to create children's personalities most, who mediate information and knowledge. Unfortunately, this profession is not appreciated by the society enough.

\section{References}

Błażejewski, W., \& Lewicki, C. (2011). Merytoryczne i metodyczne postawy edukacji zawodowej: systemove ujecie zagadnien. Rzeszów: Wydawnictwo Oświatowe FOSZE.

Černotová, M. (1997). Kapitoly z pedagogiky pre študentov. Prešov: FF PU $\mathrm{v}$ Prešove.

Dupkala, R. (2004). The Prešov school: philosophy at the Evangelical College in Prešov. Prešov: Slovacontakt.

Dytrtová, J., \& Krhutová, M. (2009). Učitel - připrava na profesi. Praha: Grada Publishing.

Ďurič, L., \& Štefanovič, J. (1977). Psychológia pre učitel’ov. Bratislava: SPN.

Fontana, D. (2010). Psychologie ve školní praxi. Praha: Portál.

Határ, C. (2012). Place of senior education in the system of lifelong learning. In Teaching and learning: goals, standards and outcomes. Užice: University of Kragujevac.

Hupková, M., \& Petlák, E. (2004). Sebareflexia a kompetencie v práci učitel’a. Bratislava: IRIS.

Jakúbek, P., \& Tej, J. (2015). Reform of financial administration in the Slovak Republic. Ekonomicnij Casopis-XXI, 33 - 37.

Škvarková, Z. (2005). Spolupráca rodiny a školy v teórii a praxi. In Inovácie $v$ škole. Dolný Kubín: Občianske združenie Orava pre demokraciu vo vzdelávaní.

Švec, Š. (2002). Základné pojmy v pedagogike a andragogike. Bratislava: IRIS.

Tamášová, V. (2015). Profesional and Career Development of Vocational Subject Teachers as a Trend in the Lifelong Learning of Teachers. Acta Technologica Dubnicae, 5(1), 1-20. doi: 10.1515/atd-2015-0029

Turek, I. (2009). Kvalita vzdelávania. Bratislava: Iura Edition.

Višňovský, L', \& Kačáni, V. (2005). Psychológia a pedagogika pomáhajú škole. Bratislava: SPN. 